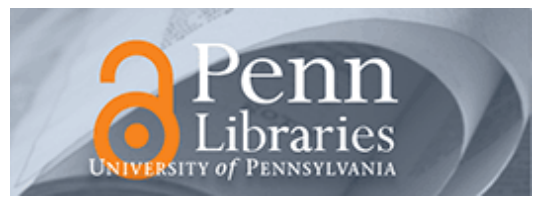

University of Pennsylvania

ScholarlyCommons

Real Estate Papers

Wharton Faculty Research

$12-2005$

\title{
Do Low-Income Housing Subsidies Increase the Occupied Housing Stock?
}

Todd Sinai

University of Pennsylvania

Joel Waldfogel

Follow this and additional works at: https://repository.upenn.edu/real-estate_papers

Part of the Economics Commons, and the Real Estate Commons

\section{Recommended Citation}

Sinai, T., \& Waldfogel, J. (2005). Do Low-Income Housing Subsidies Increase the Occupied Housing Stock?. Journal of Public Economics, 89 (11-12), 2137-2164. http://dx.doi.org/10.1016/ j.jpubeco.2004.06.015

This paper is posted at ScholarlyCommons. https://repository.upenn.edu/real-estate_papers/66

For more information, please contact repository@pobox.upenn.edu. 


\title{
Do Low-Income Housing Subsidies Increase the Occupied Housing Stock?
}

\begin{abstract}
A necessary condition for justifying a policy such as subsidized low-income housing, either via tenantbased rental assistance or construction of public or private projects, is that it has a real effect on market outcomes. In this paper, we examine one aspect of the real effect of subsidized housing-does it increase the housing stock? If subsidized housing raises the quantity of occupied housing per capita, either more people are finding housing or they are being housed less densely. On the other hand, if subsidized housing merely crowds-out equivalent-quality low-income housing that otherwise would have been provided by the private sector, the housing policy may have little real effect on housing consumption. Using both Census place and MSA-level data from the decennial census and from the Department of Housing and Urban Development, we ask whether housing markets with more subsidized housing also have more total housing, after accounting for housing demand. We find that government-financed units raise the total number of units in a market, although on average one government-subsidized unit adds only one-third to one-half of a unit to the total housing stock. There is less crowd-out in more populous markets, and more crowd-out in places where there is less excess demand for subsidized housing, as measured by the number of government-financed units per eligible person. Tenant-based housing programs, such as Section 8 Certificates and Vouchers, seem to be more effective than project-based programs at targeting subsidized housing units to people who otherwise would not have their own.
\end{abstract}

\section{Keywords}

public-housing, low-income housing, crowd-out

Disciplines

Economics | Real Estate 


\title{
Do Low-Income Housing Subsidies Increase the Occupied Housing Stock?
}

\author{
Todd Sinai \\ The Wharton School \\ University of Pennsylania \\ and NBER \\ Joel Waldfogel \\ The Wharton School \\ University of Pennsylania \\ and NBER
}

January 29, 2004

The authors thank the Zell-Lurie Real Estate Center at Wharton for supporting this project. We appreciate the helpful comments of two anonymous referees, the editor Thomas Piketty, Amy Bogdon, Chris Mayer, John Quigley, Scott Susin, and the participants at the 2001 AREUEA mid-year meetings and 2003 AEA Meetings. All views - as well as any errors - are the sole responsibility of the authors. Correspondence can be sent to: Todd Sinai, The Wharton School, University of Pennsylvania, 308 Lauder-Fischer Hall, 256 South $37^{\text {th }}$ Street, Philadelphia, PA 19106-6330. (215) 898-5390. E-mail: sinai@wharton.upenn.edu. 


\title{
Do Low Income Housing Subsidies Increase the Occupied Housing Stock?
}

\begin{abstract}
A necessary condition for justifying a policy such as subsidized low-income housing, either via tenant-based rental assistance or construction of public or private projects, is that it has a real effect on market outcomes. In this paper, we examine one aspect of the real effect of subsidized housing - does it increase the housing stock? If subsidized housing raises the quantity of occupied housing per capita, either more people are finding housing or they are being housed less densely. On the other hand, if subsidized housing merely crowds out equivalentquality low-income housing that otherwise would have been provided by the private sector, the housing policy may have little real effect on housing consumption. Using both Census place and MSA-level data from the decennial census and from the Department of Housing and Urban Development, we ask whether housing markets with more subsidized housing also have more total housing, after accounting for housing demand. We find that government-financed units raise the total number of units in a market, although on average one government-subsidized unit adds only one-third to one-half of a unit to the total housing stock. There is less crowd-out in more populous markets, and more crowd out in places where there is less excess demand for subsidized housing, as measured by the number of government-financed units per eligible person. Tenant-based housing programs, such as Section 8 Certificates and Vouchers, seem to be more effective than project-based programs at targeting subsidized housing units to people who otherwise would not have their own.
\end{abstract}

JEL Codes: H42, R21, R31 
Through various levels of government, the U.S. spends a considerable sum subsidizing low-income housing, over $\$ 25$ billion in budget outlays on an annualized basis. ${ }^{1}$ These subsidies include both project-based programs such as public housing and Section 8 New Construction and tenant-based voucher programs, such as Section 8 existing housing assistance, that aim to shoulder a portion of the cost of privately provided housing. The implicit rationale underlying both project and tenant-based programs, which we refer to collectively as "subsidized housing," is that, in the absence of government intervention, poor people would consume inadequate amounts of housing. ${ }^{2}$

In spite of the large expenditures on these programs, it is far from obvious if they have any effect on whether families have their own housing units (as opposed to sharing a unit with another family or being homeless). It is possible, instead, that these programs simply transfer resources to families that would be housed even in the programs' absence. If so, one might regard the programs as wasteful and ineffectual, although such a conclusion would not necessarily follow as subsidies might allow households to occupy better housing units. In this paper we ask whether low-income housing subsidies satisfy a simple sufficient condition for effectuality: do they increase the number of families housed in their own units or do they simply crowd-out privately-provided low-income housing? In particular, if subsidized housing raises the quantity of occupied housing units per capita, either more people are finding housing or they are being housed less densely.

Using cross-sectional data on total housing, subsidized housing, and population (and other demand shifters) in 22,872 Census designated places - and $252 \mathrm{MSAs}$ - we find neither

\footnotetext{
${ }^{1}$ HUD outlays alone reached roughly $\$ 25$ billion per year in the mid-1990s. The amount is much larger if one also includes USDA programs accounting for over 20 percent of subsidized units and the tax expenditure for the Low Income Housing Tax Credit, which costs about $\$ 3$ billion per year (see Olsen, 2001).

${ }^{2}$ See Olsen (2001) for a clear discussion of the possible rationales for subsidizing housing expenditure.
} 
complete crowd out, nor that subsidized housing is all net new. We estimate that an additional subsidized unit raises the total number of units in a place or MSA by between 0.35 and 0.52 units. Lending credibility to the estimates, we find that crowd out is smaller in markets with more excess demand for the existing subsidized housing stock, measured as the number of families potentially eligible for subsidized housing per existing subsidized unit.

The impact of subsidized housing on the long-run housing stock depends on the way that the housing is allocated to families. If a unit in a public or private subsidized project, or a voucher for use toward a privately supplied unit, is awarded to a family that currently boards free of charge with another family and would otherwise not have purchased its own housing services, then the unit will be a net addition to housing consumed and no crowd out will occur. Remaining demand for private housing will not decline and in the case of a voucher an additional private unit will be built to replace the one rented by the subsidized family, presuming the long run supply of low income housing is elastic. On the other hand, if the subsidized unit is awarded to a family that would have purchased some housing services in the absence of the program, then the program may have little effect on the quantity of housing consumed. Indeed, consistent with their reported goals, tenant-based programs seem to be doing a better job of targeting families who would not otherwise consume their own unit. An additional housing unit provided through this mechanism yields 0.7 units of net new housing while project-based housing generates less than 0.3 units of net new housing. If the goal of low-income housing programs is to house families that would otherwise not have their own units, then resources should be targeted to places with more eligible families relative to the existing stock of government-financed units or distributed through programs with sufficient flexibility to allocate the subsidies to the neediest families. 
Our inquiry is related to two strands of existing research. First, this is one of many studies of whether government programs crowd out private activity. Other recent studies on this basic topic include Cutler and Gruber (1996), on whether public insurance crowds out private insurance, and Berry and Waldfogel (1999), on whether public radio broadcasting crowds out commercial broadcasting. ${ }^{3}$ Two studies by Murray $(1983,1999)$ examine how subsidized housing crowd outs housing construction and the private housing stock. ${ }^{4}$ Murray (1983) asks whether public housing crowds out private housing using time series regressions of private housing starts on public housing starts. The relationship between public and private starts does not illuminate the equilibrium relationship between public housing subsidies and the stock of private housing. Closer to our question, Murray (1999) estimates a vector autoregression on 27 years of the stock of subsidized and private housing units. He concludes that public housing units added to the total housing stock but that moderate income subsidies did not. By contrast, we take a cross sectional approach with a large number of observations. The focus of our study is instead on market-level equilibrium. Using cross sectional data that we presume describe a long-run equilibrium, we ask how the equilibrium in the private housing market responds to the extent of subsidized housing in a market. $^{5}$

The second strand of research relating to this study is the literature on the effect of subsidized housing on homelessness. Early (1998) finds that existing subsidized housing has not targeted those most at risk of homelessness and that its expansion would not clearly reduce

\footnotetext{
${ }^{3}$ Government crowding out of private activity is a fairly generic phenomenon. Major additional contexts include Social Security and private saving (Feldstein, 1982) and program expenditure and charitable giving (Kingma, 1989), to name a few.

${ }^{4}$ Susin (2002) finds that rent vouchers lead to substantially higher rents for unsubsidized low-income units. He attributes this result to higher voucher-driven demand in the low-income segment of the housing market combined with a low elasticity of supply of such housing. However, it is not clear that the supply elasticity in the low-income market is inelastic. [DiPasquale (1999)]

${ }^{5}$ Since it takes some time for the private housing market to fully respond, we believe an equilibrium analysis, rather than a time series analysis, is most appropriate.
} 
homelessness. Early \& Olsen (2002) find that housing subsidies targeting very poor households have large and significant effects on homelessness.

This paper proceeds in four sections. First, we review the basic low-income housing subsidies and lay out a simple framework for analyzing their effect. Second, we describe the data used in the study. Third, we present evidence on the impact of subsidized housing on overall housing consumption. A brief conclusion follows.

\section{Background and Mechanisms}

\section{Market Mechanism}

Housing subsidy programs fall into two basic categories: project-based and tenant-based. Project-based programs, such as public housing and Section 236 , use government funding to supply housing units. Tenant-based programs, such as the Section 8 certificate and voucher program, give recipients a form of assistance to pay for some or all of the rent for a private unit. While in many ways quite different, these programs share the essential feature that program administrators ration access to the program's housing. That is, certain criteria must be met to be eligible for subsidized housing, but not all eligible families receive subsidized housing, and the most poorly housed families do not necess arily receive priority for subsidized housing. The key question for how both programs affect housing market equilibrium is whether the families awarded housing under the programs would have dwelt in their own units in the absence of the programs.

Subsidized housing, even project-based housing, is not necessarily free housing. A family that meets the eligibility criteria still needs to pay some rent, with an amount typically defined as a percent of family income. The primary programs through which HUD provides 
subsidized housing all require such a tenant contribution. ${ }^{6}$ The first program is Public and Indian Housing. Since 1937, HUD has paid the construction costs, and more recently the operating costs not covered by tenant rents, of public housing projects run by Public Housing Authorities (PHAs) or Indian Housing Authorities (IHAs). Tenants currently are required to pay 30 percent of their incomes as rent.

Section 8 new construction and rehabilitation, in place from 1974 to 1983 , subsidized private developers to build new housing or convert existing buildings into low-income housing. In addition, tenants' rent was subsidized by HUD with HUD covering the differential in rents between what the tenant is required to pay and the fair market rent in the area. ${ }^{7}$ As of 1983 , no additional units were funded under this program, though funding was continued for existing obligations. ${ }^{8}$

Over the last two decades, low income housing policy has shifted from government subsidization of project-based housing construction (such as public housing) tow ard a reliance on tenant-based assistance, such as certificates and vouchers. ${ }^{9}$ Project-based housing in the US was constructed mainly in the $1960 \mathrm{~s}$ and 1970 s. As Poterba (1994) documents, new projectbased housing starts slowed from 24,000 units in 1980 to a trickle in the late 1980 s $(2,000$ to 3,000 per year during 1985-1987). Project-based assistance continues to comprise the majority of subsidized housing units, but the growth in tenant-based assistance has been much more rapid. From tables in Olsen (2001) we compute that the tenant-based share of subsidized units rose

\footnotetext{
${ }^{6}$ See Olsen (2001) and Quigley (2000) for excellent descriptions of the institutional details and history of public housing.

7 "Fair market rent" is defined by HUD for each geographical area.

${ }^{8}$ Olsen (2001) reports that prior funded construction continued for more than a decade.

${ }^{9}$ There is one big exception to this statement: the Low-Income Housing Tax Credit provides a tax subsidy to private developers if they make their units available to a sufficient number of low-income families. The LIHTC is the second largest and most rapidly growing low-income housing program in the U.S., already housing about 1.3 million families. [Olsen (2003)]
} 
from 8 percent in 1976 to about 25 percent in the early 1990 s, where it held steady through 1998 , the end of Olsen's data. ${ }^{10}$

The Section 8 Housing Assistance Program was HUD's tenant-based assistance program during our sample period. Eligible participants received either certificates or vouchers good for, at best, the difference between HUD's assessment of fair market rent and 30 percent of their income. Under the certificate program, the tenants must have located a unit that met minimum quality standards and did not rent for more than the fair market rent. They paid their share and the HUD certificate covered the remainder. The voucher program did not place a cap on the market rent of the unit. The tenants simply received a voucher for the difference between the fair market rent and the tenant's contribution; if the tenant chose to rent a more expensive unit they could pay the difference out of pocket. If they chose a less expensive unit, their contribution was reduced.

Table 1 provides a summary of the size of various programs targeted at low-income renting families in 1996. A total of eight basic programs provided 4.81 million housing units, or 4.2 percent of the nearly 116 million housing units in the U.S. ${ }^{11}$ By far the largest programs are Section 8 Certificates \& Vouchers (1.35 million units) and Public Housing (1.33 million units). The Section 8 New \& Substantial Rehabilitation program provides 0.90 million units. Other subsidized construction programs include Section 236 ( 0.45 million units), the Low Income Housing Tax Credit ( 0.33 million units), Section 8 Moderate Rehabilitation ( 0.11 million units), Indian Housing ( 0.07 million units) and miscellaneous other programs providing a total of 0.29 million units.

\footnotetext{
${ }^{10}$ These figures treat Low-Income Housing Tax Credit funding commitments as actual units available for occupancy. In reality, this overestimates the availability of LIHTC units and thus underestimates the tenant-based share of subsidized housing.

${ }^{11}$ Source: "Census 2000 Quickfacts," http://quickfacts.census.gov/hunits.
} 
To receive a subsidized unit, one must satisfy a fairly complicated set of eligibility criteria and also be selected from within the pool of eligible applicants. The primary restriction on eligibility is income. A family of four can earn no more than 80 percent of their area's median income to be eligible. ${ }^{12}$ During our sample period, Congress had enacted preferences for "very low income" families: to be so classified, a family of four must have an income less than 50 percent of the median. ${ }^{13}$ Choosing which families from the large pool of eligibles would receive subsidized housing is up to each of the approximately 3400 local housing authorities. ${ }^{14}$ During our sample period, preference was typically given to the elderly, people living in "substandard" housing, and those paying more than 50 percent of their income as rent. [Olsen $(2001)]^{15}$

\section{Market Effects}

One might expect that programs that directly increase the supply of housing (such as public and Indian housing, as well as some parts of Section 8) would affect the housing market differently than programs such as Section 8 Certificates and Vouchers that operate on the demand side. Yet, all of these programs share an important feature: administrators choose how to allocate housing to eligibles, leaving the remainder of the (private) market to equilibrate. ${ }^{16}$ The process of allocating housing units (or vouchers, as we shall see below) provides the demand management that determines the equilibrium impact of the program.

\footnotetext{
${ }^{12}$ This cap varies with family size.

${ }^{13}$ In addition there are now some preferences for families with incomes below 30 percent of the median, though these rules were not in effect during the time period covered by our data.

${ }^{14}$ Similarly, the owners of privately subsidized projects select their tenants.

${ }^{15}$ Some of these preferences were eliminated in the Housing Act of 1998.

${ }^{16}$ For the purpose of this exposition, it is easiest to view privately owned units that are rented using Section 8 certificates or vouchers as publicly supplied housing. One can view the future stream of Section 8 payments that the landlord will receive as the means by which the housing is purchased for the virtual public stock.
} 
It is instructive to consider the effects of the two basic kinds of housing programs using simple supply and demand analysis. We first consider subsidized project-based housing. Project-based units are public supply. ${ }^{17}$ When they are built they shift aggregate housing supply out. If prices adjust so that markets clear, then the number of units consumed will initially rise by the number of project-based units made available. How the project units are allocated, however, determines whether in the long run they raise housing consumption. To begin with one extreme, suppose that each new project-based housing unit is allocated to a family that was formerly unable to purchase housing and was living rent-free with another family. Then the subsidized housing policy provides both new demand and new supply. ${ }^{18}$ The unit occupied by the recipient family represents a transaction that would otherwise not have occurred. This transaction, however, has no effect on the private market. Because the family would not have purchased housing in the private market, private demand for units is not reduced. ${ }^{19}$ Because the new supply is rationed only to families with no private demand, the public supply has no effect on the private market. Put another way, the project-based unit would raise the total housing stock by one unit. No crowd out would occur.

At the other extreme, had the subsidized unit been given to an inframarginal family - one purchasing its own private housing unit without the program, the program would reduce demand for private housing. With such an allocation scheme, the equilibrium impact of the project-based housing unit would be a reduction by one in the number of private units. Put another way, the

\footnotetext{
${ }^{17}$ Almost all project-based assistance is used to develop new units, either through subsidized construction or major rehabilitation.

${ }^{18}$ That is, the recipient enjoys an income transfer in the form of in-kind rent, which raises demand.

${ }^{19}$ Although the rent-paying family that remains may wish to reduce its consumption of space since its roommates moved out, it still needs a unit.
} 
subsidized housing unit would not raise the number of units in the housing stock. Crowd out would be complete. ${ }^{20}$

A possible middle ground would occur if the new recipient of subsidized housing contributes some but not all of the rent. That family moves into new housing, leaving behind a family that now cannot afford their unit by themselves. However, they now can pair up with another family who is no longer sharing its unit, leading to the abandonment of one private unit. In this example, for every four families that were occupying two units, an allocation of one unit of subsidized housing to each pair would lead to three occupied units in the end, a net addition of one or equivalently 50 percent crowd-out.

While voucher programs do not directly lead to the construction of additional units, their potential effect on demand is the same. A certificate or voucher can be awarded to a family that would have purchased private housing in the absence of the program, or it can be awarded to a family that would not have purchased such housing. In the former case, demand for housing where landlords do not accept vouchers falls by the number of voucher units allocated. Vouchers do not raise the number of units in the stock, and crowd out is complete. In the latter case, demand for non-voucher housing is unaffected. In the long run vouchers provide new demand, and the private market responds with additional private units. Again, a middle ground of partial crowd-out is also possible.

Thus far, our exposition has assumed that the long run supply of privately-provided low income housing is perfectly elastic and thus the quantity of low-income housing adjusts to public subsidies but not the price. If the housing supply curve is upward-sloping in the long run,

\footnotetext{
${ }^{20}$ In the short run, constructing subsidized housing units would increase the aggregate housing supply in a market. However, the resulting lower house prices would lead to fewer additional units being constructed than otherwise would have. If the subsidized housing units were of a higher quality than the private housing they displaced, the overall quality of low income housing could increase without any apparent change in the number of units.
} 
presumably due to an inelastic supply of land or other inputs, the degree of crowd out when measured in terms of units would be larger. A newly constructed subsidized unit allocated to a family not already consuming a unit would lead to higher land prices and thus rents in the long run. At those higher rents, private housing demand would decline, partially offsetting some of the increase in housing stock.

In the short run, if there are useable vacant units in the market, housing supply is very inelastic since the stock of existing housing does not quickly disappear. [Glaeser and Gyourko (2001)] In that case, the degree of crowd out may differ between subsidies for new construction and existing housing. If low income housing subsidies lead to new units being built, the supply of housing will increase without a commensurate rise in demand. The tenants who move into the newly constructed subsidized housing will reduce demand for the inelastically supplied private housing stock, lowering rents. At those lower rents, demand for private units may increase, leading to more than a one-for-one increase in total units. But if vacant private units are purchased for the subsidized stock, as with vouchers, the overhang of private vacant units will be reduced, leading to a rise in private market rents.

Although the empirical evidence is mixed, most surveys of the general housing supply literature conclude that the supply of housing units is fairly price elastic, at least on a national level. [DiPasquale (1999), Olsen (1987), Whitehead (1999)] In contrast, recent research [Susin (2002)] presents evidence that the long-run housing supply elasticity is low. While we cannot resolve the housing supply elasticity question in this paper, two points are in order. First, the possibility of inelastic supply shrinks the possible effect of subsidies on housing consumption and thus makes any effect more difficult to identify. Second, a low supply elasticity implies that housing consumption should respond differentially to tenant and project-based subsidized 
housing. If supply is inelastic, then voucher policies which directly stimulate only demand should have smaller effects on quantity than project-based housing programs which (unless they are accompanied by demolition) stimulate both supply and demand. As we will see in the empirical section, tenant-based housing has a bigger effect on the consumption of units than project-based housing, consistent with relatively elastic long run supply.

Our schematic description leaves out a few important features of the housing market. First, we are focusing on units. Even if a subsidized housing program has no effect on the number of units in the stock, it may affect the quality of units consumed. Second, a subsidized housing program may affect where recipients choose to live in potentially beneficial ways. [Katz et al (2001)] Finally, we are abstracting from the income transfer portion of the program. Rent subsidies, even to people who would have rented their own unit in the absence of the program, is one way of transferring income to the needy. Subsidized housing may provide a way for families with high rent burdens to reduce the proportion of their incomes they devote to housing, even if they are already housed. In addition, if subsidized housing is sufficiently stigmatized it may be an optimal way of identifying valid recipients of public assistance. [Nichols and Zeckhauser (1982)]

\section{Data}

The ideal unit of observation for our study would be a market area. That is, we are trying to ascertain the impact of subsidized housing on total housing. A narrow geographic unit, for example a census tract, would be inappropriate as a unit of observation for our study because the private housing built in the adjustment to the new equilibrium following the introduction of subsidized housing would likely be outside the tract. It is not obvious what level of geography 
corresponds to the housing market, so we employ two approaches. First, we employ a cross section of 22,872 Census designated places. Places are political units such as cities and towns. ${ }^{21}$ Places would be an adequate unit of observation if private market adjustment to the low-income housing programs occurred inside of the political jurisdictions where the subsidized housing is located. Yet small places, such as suburbs of large metropolitan areas, may be components of larger metropolitan housing markets. If subsidized housing attracts eligibles to places, then estimates using places may overstate the stimulating effect of subsidized housing on the overall housing stock. To deal with this we also employ a second approach, using the 252 Metropolitan Statistical Areas (MSAs) as our observations on markets. Since MSAs are designed to encompass an economic area rather than a purely geographic one, we suspect that MSAs fully contain housing markets while small Census places may not. On the other hand, aggregating to just 252 MSAs masks much of the variation we might use to identify our effects.

Our basic cross section matches data on total housing stock, population, and other demand determinants in each Census place and MSA from the 1990 decennial Census with data on the number of subsidized housing units, also by Census place and MSA, for 1996 from HUD's "A Picture of Subsidized Households - 1996." The HUD data set reports project- and housing authority-level data that we aggregated up to the Census place and MSA level. While the timing of the matches between the subsidized housing and the Census data is imperfect, it is the best we could obtain. ${ }^{22}$ In addition, we have earlier 1977 HUD data, as well as 1980 Census data which we use to create instruments, as we outline below.

\footnotetext{
${ }^{21}$ We exclude places with a ratio of subsidized units per capita greater or equal to 0.5 , as well as places with 1.1 or more total housing units per capita. These restrictions keep places such as resort communities, with many housing units but few permanent residents, out of the sample.

${ }^{22}$ Although HUD maintains a data set on subsidized housing in 1993 (See http://www.huduser.org/data/data.html for information on Family Data on Public and Indian Housing (1993)), that data source contains information only on projects, not certificate and voucher programs. According to HUD employees, it appears that historic subsidized
} 
Table 2 reports the means and standard deviations across both places and MSAs of some of the data we use most frequently, weighted by their respective populations. Since means at both levels of geography look very similar, we focus on Census places. On average, about 2.7 people live in each housing unit (1/0.376). There is less than one subsidized housing unit for every 50 people in the U.S. (a ratio of 0.018$)$, of which 72 percent $(0.013 / 0.018)$ is project-based housing and 28 percent is tenant-based. The "pressure" variable, which we will explain in more detail below, indicates that there are three times as many potentially eligible recipients of subsidized housing than there are units. About 13 percent of the population in these Census places is over 65 years of age, and approximately 14 percent are Black. Nearly 40 percent are married and 20 percent did not live in their current county five years prior. (At the MSA level, 17 percent did not live in the same MSA five years before.)

Subsidized housing is disproportionately concentrated in large places. As table 3 shows, 93.4 percent of subsidized housing is located in the top 25 percent of markets, while these markets contain 88.0 percent of total housing and 88.5 percent of the population. The top percentile of places contains just over half the subsidized housing in the U.S. The same places contain just over a third of the population and total housing units. Indeed, the top 35 markets, listed in table 4 , together include 22 percent of subsidized housing. New York City alone has a quarter of a million subsidized units, about 7.5 percent of the national total. However, at the MSA level, represented in the second panel of table 3, subsidized housing units are evenly distributed with respect to population.

housing data was not archived. Thus it is impossible to go back and construct data on the quantities of subsidized housing in, say, 1990. 


\section{Empirical Strategy and Results}

Our empirical approach asks whether markets with more subsidized housing have more total housing units, after accounting for other potential determinants of the number of housing units. If markets with more subsidized housing units do not have more total housing units than they would have in the absence of subsidized housing, we can conclude that subsidized housing does not increase the housing stock and must have crowded out private provision of low-income housing. If markets with more subsidized housing units have a greater number of total housing units, all else equal, some subsidized housing must be net new. We recognize the possibility that the number of subsidized housing units may be correlated with unobserved determinants of housing demand, so we also employ an instrumental variables strategy that we describe below.

To measure the impact of low-income housing policy on the private housing market equilibrium, first we regress the total quantity of housing in a market on the quantity of subsidized housing in the market. Because housing markets differ enormously in size, we run the regressions in per capita terms, weighting using population. This cross sectional strategy assumes private housing markets are in equilibrium. That is, the private housing stock must have fully adjusted to the presence of subsidized housing. If project-based housing has been constructed or vouchers funded recently, the private market may not have had time to respond, biasing our results. For example, unanticipated construction of a project-based unit increases the housing stock by one unit in the absence of depreciation (since no private units have been removed from the housing stock). Similarly, allocating a new voucher would have no effect on total housing in the short run since private developers would not yet have had the opportunity or time to build anew. These outcomes would make project-based housing look very effective and tenant-based housing look like it had no effect on housing consumption, even if in the long run 
the private housing market would have fully responded. ${ }^{23}$ Of course, the private market response may be fairly rapid. If subsidized housing is constructed, private housing units do not have to fall down for the market to reach equilibrium. If there is population growth, developers simply can construct less new supply than otherwise would have been the case. Also, if the construction or funding of subsidized housing is anticipated, then developers can more readily adapt.

To surmount the potential problem of short-run disequilibrium, we use the total occupied housing stock per capita as our left-hand-side variable. If a new project-based housing unit is allocated to someone who would have consumed a housing unit anyway, it will have no effect on the aggregate occupied housing stock. However, if it induces a family to move away from sharing a unit to living on its own, the new housing will increase the number of occupied units. Similarly, we use occupied subsidized housing units per capita as our independent variable. ${ }^{24}$ Using the total housing stock rather than just-occupied yields very similar results, supporting the view that private developers can quickly and easily adjust. ${ }^{25}$

The results are reported in table 5. Specification one uses observations on Census places and includes the distribution of race, the distribution of age across 12 categories, the distribution of family income across 25 categories, and the percent of the population that is married as controls. ${ }^{26}$ The second specification adds state fixed effects to control for possible unobserved heterogeneity. The degree of crowding-out is then identified from differences in the number of

\footnotetext{
${ }^{23}$ In fact, Murray (1999) finds the aforementioned pattern, suggesting that his time series analysis may be picking up a short-run effect.

${ }^{24}$ HUD reports occupancy rates only for project-based housing. HUD points out that the other forms of housing assistance are more-or-less fully occupied and reports the data accordingly. Whether we use occupied or total subsidized housing is inconsequential.

${ }^{25}$ The standard errors are comparable and the point estimates on the public subsidized variable varies by about 0.10 .

${ }^{26}$ We have also replicated the regressions in this paper adding the percent of families with children as a control variable. Including it has almost no effect on the coefficients of interest, and we are concerned about its potential endogeneity, so we do not incorporate it in our reported results. We are less concerned with the potential endogeneity of the share of people in a housing market who are married so we include it as a control; leaving it out has little-to-no effect on the measured degree of crowding-out.
} 
subsidized housing units across places within the same state. The coefficient on total subsidized housing per capita varies from around 0.28 to about 0.35 , and is large relative to its standard error. $^{27}$ We can clearly reject both that the coefficient is zero and that it is one. Thus, the full sample estimates are inconsistent with both full and zero crowd out, suggesting instead that three additional subsidized units add one unit to the aggregate stock, crowding out about two private units. ${ }^{28}$ The controls explain a significant fraction of the cross-sectional variance in occupied housing units per capita, almost 80 percent.

The third and fourth columns revisit the first two specifications using MSAs rather than places as the unit of observation. We find completely consistent results, despite the lower power due to the higher level of aggregation. ${ }^{29}$ Our estimated coefficient on subsidized housing in column $3(0.17)$ is about 50 percent smaller than in the comparable places regression. Given the standard error, the coefficient is not statistically different from zero but it is clearly far from one. In column (4), we add state dummies to the MSA regression. Since some MSAs cross state lines, we assign them to the states that contain the largest fraction of their populations. ${ }^{30}$ Using the within-state variation, we find that one additional subsidized housing unit in an MSA leads to a statistically significant 0.52 increase in total housing units.

\footnotetext{
${ }^{27}$ If subsidized housing is not independently allocated across Census places then we underestimate the standard errors. One could imagine a number of possible correlations, such as within metro area or more generally across space. Rather than model the error structure explicitly, we take two alternative approaches. First, the MSA-level regressions reported below are almost certainly provide an upper bound on the standard errors since they assume zero independence within MSA. Second, we have estimated this regression using just the 10,506 observations on Census places that are in MSAs and including MSA fixed effects. The point estimates and statistical significance change little.

${ }^{28}$ Since we have data on public housing in 1977 we could run an analogous set of regressions for public housing's crowd out in 1980 . When we do so, the results are economically and statistically similar.

${ }^{29}$ The differences in the point estimates are not due to changes in the geographies covered by places versus MSAs. When we repeat the place-level estimation using only places that are contained in MSAs, we obtain results very similar to those in the first two columns.

${ }^{30}$ Controlling with the share of population in each state yielded virtually the same results.
} 
Because subsidized housing is skewed toward large places, we re-estimate the equations for each quartile of places, ranked by population. ${ }^{31}$ Columns one and two of table 6 replicate the specifications in table 5 and report just the coefficient on occupied subsidized housing in each quartile regression. A pattern that emerges is that crowding out is lower in larger places. ${ }^{32}$ In the bottom quartile, each subsidized unit adds only 0.06 of a unit to the long-run housing stock. But in places with an above the median population, each subsidized unit raises the total number of occupied units by between 0.2 and 0.4 units. Because population is skewed, with many people in the top few percent of Census places, the largest cities may drive the results in columns 1 and 2. Specification 3 , rather than weighting each place by population, weights each Census place equally. This emphasizes where in the population distribution the results are coming from. The results are very similar to the weighted regression suggesting that our model is well-specified.

The results in Tables 5 and 6 show that subsidized housing displaces the private provision of low-income housing. Of course, this does not imply that differences in subsidized housing across locations explain the variation in the number of housing units per capita. The amount of housing per capita varies considerably across places and MSAs. For example, in the last column of Table $4, \mathrm{NYC}$ has 2.45 persons per unit, LA has 2.68 , and Denver has 1.95 . For a variety of reasons, subsidized housing explains very little of these differences. As an empirical matter we can measure the upper bound on the fraction of total housing variation attributable to subsidized housing as the R-squared from a univariate regression of total occupied housing per capita on per capita subsidized housing. The coefficient on subsidized housing in this regression is 0.84 , and the R-squared is 5 percent. Thus, 5 percent is an upper bound on the fraction of

\footnotetext{
${ }^{31}$ There are not enough MSAs to estimate the quartile regressions at the MSA level.

${ }^{32}$ In part, this is due to the fact that in larger places a greater share of the subsidized units are tenant-based and that form of assistance exhibits less crowding-out. We will show this in more detail in table 7. Also, in larger places there is a larger needy population relative to the availability of subsidized units. We will show in table 6 that this kind of excess demand leads to lower crowding-out.
} 
housing variation explained by subsidized housing. Because subsidized housing is correlated with other determinants of total housing, the true effect of subsidized on total housing differs from the coefficient in the simple regression. With other covariates and state dummies included, the increment to R-squared from adding the subsidized housing variable is 0.28 percent, and the coefficient on subsidized housing becomes much smaller, at 0.52 , although it remains statistically significant.

There are several reasons why subsidized housing is not an important determinant of the cross-sectional variation in units per capita. First, there is crowd-out itself. In a world with complete crowd-out, after accounting for other determinants of housing demand, total housing would be constant across place, and subsidized housing would therefore explain none of its variation. To the degree crowd-out is partial, the explanatory power of the subsidized housing stock is mitigated. Second, much of the cross-sectional variation is due to other factors that influence housing demand, such as income and family structure. When we include just observable covariates, and not subsidized housing, 91 percent of the variation in housing units per capita at the MSA level can be explained. Adding state dummies brings the R-squared up to almost 96 percent. Finally, subsidized housing accounts for a fairly small number of housing units. Thus there is not much scope for differences in subsidized housing to explain much of the variation in the number of total housing units per capita.

The fact that subsidized housing is not a large component of the cross sectional variation in total housing units per capita does not imply that the crowd out of private housing by subsidized housing is not large or significant - it still is. However, it is just one component among many that affect this market. That is why we focus on the crowd-out phenomenon rather than trying to explain all the considerable variation in units per capita. 
However, the substantial observable cross-sectional differences in housing units per capita may lead one to worry that there is also unobserved heterogeneity that is correlated with subsidized housing, leading to a spurious result. We explore both of these possibilities below in section 3.3. It will turn out that is not the case. If anything, places with few units per capita are more likely to have subsidized housing, leading us to underestimate the degree of crowd-out.

\section{Crowd Out and the Pressure on Subsidized Housing}

Because subsidized housing adds to the low income housing stock only to the degree that the recipients of the subsidy could not obtain a unit otherwise, one might expect that subsidized housing would have a larger average effect on the number of occupied units in places where there is more excess demand for it, or demand "pressure." That is, we expect crowd-out to be smaller in markets where the subsidized housing is scarce relative to the local low-income population. In those places, the subsidized units are more likely to have been awarded to recipients with worse housing alternatives in the absence of the program. ${ }^{33}$ Finding this pattern will also lend additional credence to our estimation approach.

We proxy for the excess demand for subsidized housing with the ratio of the existing supply of subsidized housing to the number of households we estimate are likely to be eligible for it. We estimate the number of eligible recipients by applying the Federal eligibility criteria to Census data. ${ }^{34}$ According to subsidized housing eligibility rules, a family of four is typically

\footnotetext{
${ }^{33}$ In theory, subsidized housing is supposed to be awarded to the neediest households first. However, even if that does not occur in practice, our "pressure" test will still work, as long as the average subsidized housing recipient in a high-pressure place is less likely to consume a private unit in the absence of the subsidized housing program. For example, suppose there were two types of families, those with private units and those without. Places with higher measured pressure simply have a higher fraction of families "without." An allocation rule that randomly distributed subsidized housing to the population would still have less crowd out in the high pressure areas. Allocating subsidized housing to the unhoused first would magnify the differences in the effect of subsidized housing on total housing.

${ }^{34}$ One could imagine using the length of the waiting list or the local eligibility rules for this purpose. However,
} 
eligible if its income falls short of 50 percent of the local family median income. ${ }^{35}$ Using data on the number of families in each of the 22 income cells, we compute rough numbers of eligible families per Census place. ${ }^{36}$ We then calculate an index which is the number of subsidized units per eligible family. For markets where this index is small, the pressure on subsidized housing is greater.

We then allow the extent of crowd out to differ across places according to the amount of pressure on subsidized housing by adding an interaction of subsidized housing per capita with the index. Because we expect more crowding out where there is less pressure on the government-supported low-income housing stock, we expect a negative coefficient on the interaction term. We also control for the level of low-income housing pressure by including it directly as a covariate in case it reflects otherwise unobserved heterogeneity.

Table 7 reports the estimated coefficients on subsidized housing per capita, demand "pressure" on subsidized housing, and the interaction of the two, using the place-level data. The specifications mirror those in table 5. If there were no subsidized units in a market, we find that an additional unit of subsidized housing per capita would lead to between about 0.38 and 0.51 more housing units per capita.

Supporting the hypothesis that more demand pressure, which corresponds to a smaller index value, raises the average effectiveness of subsidized housing, the coefficients on the

waiting lists are poorly measured and are capped and eligibility rules vary by public housing authority and are difficult to obtain. [Olsen (2001)] As long as this proxy broadly reflects differences in the degree to which various places are sufficiently served by subsidized housing, it should be accurate enough for our hypothesis test. ${ }^{35}$ During our sample period, for projects with contracts taking effect after 1981, 95 percent of units were reserved for "VLI," or "Very Low Income," families. A VLI family of four is defined as one with income below half the local median for a family of four. As our discussion of the rules above indicates, some families with up to 80 percent of local median income may also be eligible, although spots for such families are limited. The VLI income cutoffs for families of different sizes are obtained by scaling the figure for a family of four with a nationally uniform factor.

${ }^{36}$ These estimates are "rough" for two reasons. First, we have only discrete cells, not the exact distribution of income. Second, in computing the number of eligibles we do not adjust for family size. 
interaction term of pressure and subsidized housing are uniformly negative. All are very

precisely estimated. This result implies that the efficacy of subsidized housing in generating net new housing units declines as more is available relative to the needy population. The middle three rows of the table report estimates of the effect adding one more unit of subsidized housing would have on total housing, evaluated at the $25^{\text {th }}, 50^{\text {th }}$, and $75^{\text {th }}$ percentiles of the distribution of the pressure index (among the 10,049 places with subsidized housing). ${ }^{37}$ Focusing on specification (2), we see that in places with little subsidized housing per eligible family (high pressure), an additional subsidized unit raises total housing by 0.49 units. At a place with the median value of the index, the effect falls to 0.47 . In places with relatively plentiful subsidized housing relative to the eligible population, the effect drops to 0.44 . We interpret these estimates to mean that in places with relatively more subsidized housing, the marginal recipient family would have been more likely to occupy a (private) unit in the absence of the housing policy. ${ }^{38}$

\section{Project-based versus tenant-based assistance}

To this point we have treated project-based and tenant-based assistance as having similar effects on the private housing stock. Yet, that need not be the case. Since U.S. policy is moving away from project-based subsidized housing towards more tenant-based assistance [Quigley (2000)], it would be worthwhile to determine whether vouchers and certificates lead to more or less net new housing than do project-based subsidized housing programs.

Separately identifying the crowd-out effects of project- and tenant-based programs could also shed additional light on the believability of our results. A priori, one would not necessarily

\footnotetext{
${ }^{37}$ We also estimated the regressions underlying table 7 using only those places that had subsidized housing and the results were virtually identical.

${ }^{38}$ When we repeat the estimation using MSA-level data, we find no economically significant effect on the interaction term. At this aggregated level, there is little independent variation between subsidized housing units per capita and per low-income household.
} 
expect any differential crowd-out effect between the two types of programs. If there are differences in eligibility, however, the program that is more targeted towards families that otherwise would not be housed should exhibit less crowd-out. Olsen (2001) claims that vouchers and certificates are given to more needy recipients than project-based housing since administrators want to avoid concentrations of poverty in housing projects. ${ }^{39}$ If this claim is true, we should see tenant-based programs generating more net new housing than project-based housing. ${ }^{40}$

Table 8 finds support for this hypothesis. The specifications are the same as the columns (1) and (2) in table 5, with even-numbered columns including state fixed effects. In the first two columns, we estimate the effect of project-based subsidized housing on the total stock of housing units using Census place-level observations. ${ }^{41}$ An additional unit of occupied project-based subsidized housing is estimated to increase the total occupied housing stock by only 0.2 to 0.3 units, crowding out 0.7 to 0.8 private units. In the second two columns, an additional unit of tenant-based assistance increases the occupied housing stock by about 0.7 units, crowding out less than one-third of a private housing unit.

The regressions in columns (5) and (6) of table 8 include both project-based subsidized housing per capita and tenant-based housing per capita as explanatory variables in case the quantities of project- and tenant-based units in a Census place are related. Once again, we find

\footnotetext{
${ }^{39}$ In addition, the Low-Income Housing Tax Credit program allows landlords to charge 30 percent of the maximum eligible income -50 percent of the local median - as rent, pricing out all but the highest income eligible families.

${ }^{40}$ Other evidence suggests project-based housing has less impoverished tenants. Using the place-level data, we regressed the difference (within a Census place) in average family income between Section 8 Certificate and Voucher residents and public housing residents on the difference in average family size and a constant. The estimates show that, controlling for family size and unobserved place-level characteristics, residents in tenant-based Section 8 Certificate and Voucher units have approximately 6 percent lower incomes than residents of project-based public housing units.

${ }^{41}$ Project-based housing is defined as Public and Indian housing, Section 236, Section 8 new construction and substantial rehabilitation, the low-income housing tax credit, and "other." Tenant-based housing is Section 8 certificates and vouchers.
} 
evidence that tenant-based housing crowds out less private housing than project-based

subsidized housing does. An additional unit of project-based housing is estimated to increase the total occupied housing stock by just 0.17 to 0.28 units, while one more unit of tenant-based housing would increase the occupied housing stock by approximately 0.65 units. ${ }^{42}$ When we repeat the estimation at the MSA level, in column (7), we find a similar pattern of less crowding out from tenant-based subsidized housing. When we add state fixed effects to the MSA-level regression, in column (8), the ordering of project- and tenant-based housing reverses, but the standard errors are large enough that we cannot distinguish between the two.

\section{Robustness}

In this section we consider the robustness of our estimates to four issues: correlation of subsidized housing with unobserved determinants of housing demand, time-constant unobserved heterogeneity, migration, and how we measure the quantity of housing consumed. We examine each of these in turn.

Our empirical strategy thus far allows inference about the effect of subsidized housing on total housing if the variation in the number of subsidized housing units per capita were exogenous. If subsidized housing is located in markets for reasons related to unobserved determinants of total housing, then ordinary least squares (and other such approaches) will yield biased estimates of the effect of subsidized housing on the private housing market equilibrium.

\footnotetext{
${ }^{42}$ One should resist the temptation to extrapolate from these results that all housing programs should be tenantbased. If the differences between them are simply due to program administrators giving the vouchers to the most needy recipients, moving the project-based housing recipients into the voucher program will merely increase the amount of crowd-out due to the voucher program. It could also be that since tenant-based housing assistance is not as historically determined, it is allocated more to the places with the greatest need and thus is more effective at providing net new housing. That result does not necessarily argue for moving away from the existing project-based housing and turning towards the more flexible voucher system since it does not incorporate differences in unit quality, effectiveness of providing support services (Currie and Yelowitz (2000)), neighborhood environment (Katz et al. (2001)), or program cost. (Olsen (2000)).
} 
As we pointed out earlier, almost all project-based subsidized housing in the U.S. was built prior to the late $1980 \mathrm{~s}$. It seems likely that project-based housing, when first erected, was placed in its locations for reasons related to the prevailing demand for housing, including possibly demand factors unobservable to us. However, if the reasons for locating subsidized housing change over time (so that if subsidized housing were built today from scratch, its distribution across markets would be different), then it will be reasonable to view the quantities of project-based housing as uncorrelated with current observable housing demand determinants.

The quantity of section 8 certificates and vouchers is another matter, since they did not exist before 1976. However, the budget rules that determine the funding for each locality, and thus the number of subsidized housing units the locality can provide, is set by statute. The budgeting rules during our sample period started with the level of appropriations allocated by Congress for a given year. From that, anything previously agreed to or that needs ongoing spending must be paid. Second, HUD pays for anything Congress specially requests. Finally, the remainder is divided among allocation areas according a score that is determined by the area's proportion of the national total of: (a) the renter population ( 20 percent), (b) renters in poverty (20 percent), (c) rental occupancy that is more than 1.01 persons/room (10 percent), (d) the number of rental units needed to raise market vacancy rate to normal levels (10 percent), (e) number of rental units built before 1940 occupied by impoverished ( 20 percent), (f) other measurable conditions ( 20 percent). That division is constrained by rules that HUD cannot spend less than 0.5 percent on any single state and cannot spend less than 25 percent in nonmetropolitan areas.

Of these rules, we deem a portion of rule (e) to be reasonably uncorrelated with current housing demand. Accordingly, we will instrument with the number of units in the Census place 
built before 1940. Presumably the number of impoverished may be correlated with current unobservable housing demand so we leave that portion of the budget rule out of our instrument set.

We reestimate our base specifications on place-level data, first employing both instruments: the number of public housing units per capita in 1977-1980 and the number of housing units per capita built prior to 1940 . Then we try instrumenting with each separately. The results are reported in table 9, with the first stage regressions shown in appendix table A. Once again, the specifications mirror those in table 5.

Instrumenting seems to increase the measured crowd-out relative to table 5 . The estimated coefficient on the total occupied subsidized units drops by 75 percent (from its value in table 5) to $0.057(0.028)$. This implies that an additional subsidized unit has almost no effect on the total housing stock. However, adding state fixed effects increases the coefficient to 0.40 from its table 5 value of 0.35 . The next two panels, which include each instrument separately, suggest why state fixed effects change the estimates so much. Columns 3 and 4 show that instrumenting with the 1977 public housing units per capita leads to a finding of complete or almost-complete crowd out $(0.03$ net new units when we estimate without state dummies and 0.18 net new units when the state controls are included.) Column 5 , where we instrument with the number of housing units per capita built before 1940, finds the same effect: one subsidized unit leads to $0.16(0.05)$ net new units overall. The results obtained in column 6 , which include state dummies, show an implausibly large effect of subsidized housing on total housing. We surmise that this arises because the pre-1940 housing stock, while it varies across states reflecting historical state-by-state settlement patterns, does not vary substantially within states. This curious result explains why the column 2 coefficient exceeds its analogue in table 5 . 
While our instruments are not enormously successful, our IV results provide support for our basic OLS and fixed effects estimates showing that low-income housing subsidies increase housing consumption. For two reasons, we believe that the IV results provide a lower-bound on the true net effect of housing subsidies on aggregate housing units. First, especially in columns (3) and (4), our instrument mainly reflects the amount of public housing in an area. Because vouchers may not be allocated in the same manner as project-based housing is distributed, the IV estimates are best compared to the estimates of the effect of project-level assistance on total housing, which we document in table 8 to be much smaller than the effect of tenant-level assistance. Viewed that way, the IV estimates are not so different from the OLS results, although they are still smaller. Second, a plausible kind of endogeneity in our 1977 public housing unit instrument will tend to drive our IV results toward zero. Suppose that public housing units were allocated in greater amounts where they were most necessary, for example in places where there are too few units per capita. If the need for subsidized housing were persistent enough that the 1977 distribution were not completely exogenous in the $1990 \mathrm{~s}$, there would be more subsidized housing in places with less private-market housing, which would appear in these estimates as larger crowd-out, or little net program effect on total housing units. Another potential concern is that places with large amounts of subsidized housing have large amounts of total housing for reasons related to neither subsidized housing nor other observables. In that case, the unobserved heterogeneity would lead us to erroneously find a relationship between subsidized housing and total housing when none existed. We believe this to be unlikely. For one, the IV strategy described above should address this issue, and finds results consistent with the OLS regressions in Table 5. 
Another solution - if we had panel data on total housing, subsidized housing, and other observables, as well as exogenous variation in the change in subsidized housing over time would be to regress of the change in total housing on the change in subsidized housing, thus differencing out unobserved heterogeneity and uncovering the causal relationship between subsidized and total housing.

While we do not have all of these ingredients, we do have data on total housing per capita at the MSA level as early as 1960. About two thirds of subsidized housing in existence in 1990 appeared since 1960. As our first test, we regressed total housing in 1960 on 1996 subsidized housing and 1990 covariates. If our results were due to persistent unobservable heterogeneity, this regression should yield similar coefficients to our basic results. When we estimate these "asynchronous" models (analogous to columns 3 and 4 of table 5), we find a small and insignificant subsidized housing coefficient for the analogue to column 4 , which includes state fixed effects, and a negative and significant coefficient for the analogue to column 3 , which does not. These estimates provide substantial reassurance that the basic results are not attributable to unobserved heterogeneity.

Next, we regressed the difference in total housing per capita between 1960 and 1990 in each of the 252 MSAs on 1996 subsidized housing per capita and controls. This pseudo-panel regression pretends that there was no subsidized housing in 1960 and assumes that growth in subsidized housing since then was exogenous. Despite these strong assumptions, we again find results consistent with the OLS regressions in Table 5. With the standard set of covariates, the coefficient on occupied subsidized housing units per capita is 0.81 with a standard error of 0.31 . This indicates that each subsidized housing unit in existence in 1996 was associated with a 0.8 unit increase in total occupied units between 1960 and 1990. With state dummies, the coefficient 
on subsidized housing drops to 0.42 and while it is no longer statistically significant (standard error of 0.36 ), it is consistent with the results we found earlier.

Another issue with our estimation strategy is that an abundance of subsidized housing might attract inter-market migration of eligible persons. If so, then the size of the subsidized housing coefficient in our regressions might reflect a movement of people to housing rather than household formation within the market. ${ }^{43}$ In that case, we would overestimate the degree of crowding out. One way we have addressed this issue is to use MSAs, in addition to Census places, as our unit of observation. Any family that moves across Census places but within MSA will be correctly accounted for in our MSA regressions. Since the results are consistent between the two levels of geography, we are comfortable that within-MSA migration is not biasing our Census place results.

To address the possibility that endogenous mobility across MSAs is affecting our estimates, we have repeated our basic regressions including a variable for the amount of migration. At the Census place level, we define migration as the percent of the population who lived in a different county in 1985 , which is the highest degree of granularity available in the Census. For the MSA regressions, we use the percent of the population who lived in a different MSA in 1985. Both definitions include people who move within the U.S. as well as immigrants, with the view that population inflows may be partially determined by the generosity of the subsidized housing program.

We start by investigating whether subsidized housing and migration are related. The first three columns of table 10 report the results of regressing the number of subsidized housing units per capita on immigrants per capita as well as the usual set of controls. Column (1) finds that

\footnotetext{
${ }^{43}$ Painter (1997) finds little within-metro area moving in response to local disparities in the length of waiting lists. However, he does not provide evidence on moving across metropolitan areas to obtain public housing.
} 
Census places with more subsidized housing have less immigration. However, once we include state fixed effects in column (2), we find that within states there is a positive relationship between subsidized housing and immigration. The pattern repeats itself, with less statistical power, at the MSA level. Since the standard errors using the MSA data with state dummies are large, we report only the specification without state dummies, in column (3). ${ }^{44}$

Yet, when one controls for immigration, the coefficients of interest in the study are essentially unchanged, both at the Census place and MSA levels. Columns (4) through (9) of table 10 provide evidence of this by repeating a series of specifications from tables 5 and 7 . We find that a greater fraction of in-migrants is correlated with more occupied housing units per capita but there are virtually no changes in the estimated coefficients on any of the subsidized housing variables when we include a migration control. Even the interaction with the pressure variable, which measures excess demand for subsidized housing, remains unchanged between table 7 and columns (6) and (7) when we control for migration and even migration interacted with pressure. Hence we find no evidence that our result is attributable to migration.

One last issue concerns our measure of the quantity of housing consumed, the number of units per capita. Census places with more subsidized housing may have more housing units overall simply because of subdivision of their structures into more units rather than adding net new units. To surmount this possibility, we first try using a dependent variable that more nearly measures housing space, as opposed to units: rooms per capita. These regressions, in columns (1)-(4) of table 11, show that an additional subsidized unit raises the number of rooms per capita by about 0.5 to 1 at the place level, and 3 to 4.5 when estimated at the MSA level. Because units

\footnotetext{
44 The estimated coefficient on occupied subsidized in the MSA regression with state dummies is 0.17 with a standard error of 0.55 .
} 
contain, on average, just over five rooms, this magnitude of additional rooms is comparable to roughly 0.2 to 0.6 net new units per subsidized unit.

A potential concern with this regression is that the average size of units may vary across geographic markets in a way that is correlated with the number of subsidized units per capita. Columns $(5)-(8)$ examine the relationship between subsidized housing and unit size, and we find that Census places with one more subsidized unit per capita have 0.89 more rooms per unit, controlling for income, race, age, and marital status. However, once we add state fixed effects (in column 6), we find that having more subsidized units is correlated with fewer rooms per unit, which suggests that some of the net new units we have attributed to the presence of subsidized housing potentially might not reflect a real increase in living space. At the MSA level, subsidized housing appears to be positively correlated with rooms per unit. However, the standard errors are large so while the correlation in column (7) is statistically distinguishable from zero, the 95 percent confidence interval includes the value in column (1). With MSA data and state dummies, in column (8), the point estimate is not statistically different from zero.

To deal with potentially spurious correlation between unit size, the amount of subsidized housing, and rooms or housing units per capita, we control for the number of rooms per unit in our crowd-out regressions. When we use rooms per capita as the dependent variable, in columns (9)-(12), our results are similar to those in columns (1)-(4). Using place-level data, in columns (9) and (10), a one unit increase in the number of subsidized units per capita raises the number of rooms per capita by anywhere from $0.76(0.11$ standard error) to $0.98(0.11)$. At the MSA level the effect on new rooms per capita is not statistically distinguishable from zero in column (11). The point estimate grows large enough with the addition of state dummies in column (12) to be statistically significant but, once again, the standard error is large enough that the estimate is 
consistent with the ones found in the previous three columns. We also find that places and MSAs with larger units in terms of the number of rooms have more rooms per capita.

The last 4 columns of table 11 revisit subsidized housing's effect on the number of housing units per capita, controlling for cross sectional heterogeneity in rooms per unit. In columns (13) through (16), we see that our original result that a subsidized unit generates from one-quarter to one-third of a net new occupied housing unit is basically unchanged. The main difference is that the point estimate on occupied subsidized housing units in the MSA specification in column (3) rises to 0.25 from 0.17 , and is now significant at the 95 percent confidence level. ${ }^{45}$ The negative coefficients on the rooms-per-unit variable suggest that places with larger units have fewer units per capita.

\section{Conclusion}

A simple but natural test for subsidized housing programs is whether they allow families that would otherwise not have, to occupy their own housing units. Given equilibrium housing market responses to government programs, it is by no means obvious that programs that place families into their own housing units will raise the total number of families occupying units. The effect of such programs depends crucially on whether recipient families would have occupied their own units in the absence of the programs.

We provide a simple evaluation of this question. We ask whether places or MSAs with more subsidized housing also have more total housing, after accounting for housing demand. We find that government-financed units raise the total number of units, although on average three government-subsidized units displace two units that would otherwise have been provided

\footnotetext{
${ }^{45}$ Including both rooms per unit and immigration per capita as controls yields results very similar to these with smaller standard errors.
} 
by the private market. There is less crowd out in more populous markets, and less crowd out in places where excess demand for subsidized housing is higher because there are fewer government-financed units per eligible person. Tenant-based housing programs seem to be more effective at providing housing units to people who otherwise would not have their own. These results remain even with sensible instruments, do not appear to be driven by endogenous migration or unobserved heterogeneity, and are robust to our measure of housing consumption.

We take these results to be an indication of a positive real effect of low-income housing subsidies. Because we observe an aggregate increase in the number of units, the programs do not merely redistribute the same housing among the population. These results are also sufficient (though not necessary) for the program to have a real economic impact. Alternative effects of subsidized housing programs would make our results more difficult to find - such as subsidies affecting equilibrium rents rather than quantities of housing consumed - and often further support our conclusion of a real benefit. For example, subsidized housing may also improve the quality of housing consumed and, since it is also an income transfer, it may raise non-housing consumption.

However, much work remains. Public provision of housing is typically quite costly. [Olsen (2000)] In addition, Susin (2002) points out that if vouchers lead to higher market rents, on net the programs might transfer income from tenants to landlords. The rudimentary measures of housing consumption we examine here, the number of units and rooms consumed, is insufficient to determine whether the existing subsidized housing programs are the most efficient way of providing low income housing assistance or targeting low-income families for financial aid. All of the factors mentioned above would need to be weighed when determining whether the government should provide a private good, such as housing. 


\section{References}

Berry, Steven T. and Joel Waldfogel. "Public Radio in the United States: Does it Correct Market Failure or Cannibalize Commercial Stations?" Journal of Public Economics 71 (1999), 189-211.

Currie, Janet, and Aaron Yelowitz. "Are Public Housing Projects Good for Kids?" Journal of Public Economics 75 (2000), 99-124.

Cutler, David M. and Jonathan Gruber. "Does Public Insurance Crowd Out Private Insurance?" Quarterly Journal of Economics 111 (1996): 391-430.

DiPasquale, Denise. "Why Don't We Know More About Housing Supply?" Journal of Real Estate Finance and Economics, vol. 18 (January 1999), pp. 9-23.

Early, Dirk W; Olsen, Edgar O. Subsidized Housing, Emergency Shelters, and Homelessness: An Empirical Investigation Using Data from the 1990 Census. Advances in Economic Analysis \& Policy. Vol. 2 (1). p na02. 2002.

Early, Dirk W. The Role of Subsidized Housing in Reducing Homelessness: An Empirical Investigation Using Micro-data. Journal of Policy Analysis \& Management. Vol. 17 (4). p 68796. Fall 1998.

Feldstein, Martin. "Social Security and Private Saving: Reply," Journal of Political Economy, vol. 90 , no. 3 (1982), pp. 630-641.

Glaeser, Edward and Joseph Gyourko. "Urban Decline and Durable Housing." NBER Working Paper \#8598, November 2001.

Katz, Lawrence, Jeffrey Kling and Jeffrey Liebman. "Moving to Opportunity in Boston: Early Results of a Randomized Mobility Experiment." Quarterly Journal of Economics 116 (May 2001), 607-654.

Kingma, Bruce. "An Accurate Measurement of the Crowd-out Effect, Income Effect, and Price Effect for Charitable Contributions." Journal of Political Economy, vol. 97, no. 5 (1989), pp. 1197-1207.

Murray, Michael P. "Methodologies for Estimating Housing Subsidy Benefits." Public Finance Quarterly 6 (1978): 161-192

-------. "A Potential Hazard of Housing Allowances for Public Housing." Journal of Urban Economics. Vol. 4 (2). p 119-34. April 1977.

--------. "Subsidized and Unsubsidized Housing Starts: 1961-1977." Review of Economics and Statistics 65 (1983):590-597. 
--------. "Subsidized and Unsubsidized Housing Stocks 1935 to 1987: Crowding Out and Cointegration," Journal of Real Estate Finance and Economics 18 (1999): 107-124.

--------. "Tenant Benefits in Alternative Federal Housing Programmes." Urban Studies 17 (1980): 25-34.

Nichols, Albert and Richard Zeckhauser. "Targeting Transfers through Restrictions on Recipients." American Economic Review 72 (May 1982), 372-377.

Olsen, Edgar O. "The Cost-Effectiveness of Alternative Methods of Delivering Housing Subsidies." Mimeo, University of Virginia, December 2000.

Olsen, Edgar O. "The Demand and Supply of Housing Service: A Critical Survey of the Empirical Literature," in E.S. Mills, ed., Handbook of Regional and Urban Economics Volume 2 (1987), pp. 989-1022.

Olsen, Edgar O. "Housing Programs for Low-Income Households," NBER Working Paper \#8208, April 2001.

Olsen, Edgar O. and David M. Barton. "The Benefits and Costs of Public Housing in New York City." Journal of Public Economics 20 (1983): 299-332.

Olsen, Edgar O. "The Low-Income Housing Tax Credit: An Assessment," unpublished manuscript, February 3, 2003.

Painter, Gary. "Does Variation in Public Housing Waiting Lists Induce Intra-Urban Mobility?" Journal of Housing Economics 6 (1997), 248-276.

Poterba, James M. "Public Policy and Housing in the United States." Housing markets in the United States and Japan. Noguchi, Yukio Poterba, James M., eds., National Bureau of Economic Research Conference Report. Chicago and London: University of Chicago Press. p 239-56. 1994.

Reeder, William. "The Benefits and Costs of the Section 8 Existing Housing Program." Journal of Public Economics 26 (1985), 349-377.

Quigley, John. "A Decent Home: Housing Policy in Perspective." Brookings-Wharton Papers on Urban Affairs, 2000, pp. 53-88.

Susin, Scott. "Rent Vouchers and the Price of Low-Income Housing," Journal of Public Economics, vol. 83, no.1 (January 2002), pp. 109-152.

Whitehead, Christine. "Urban Housing Markets: Theory and Policy," in E.S. Mills and P. Cheshire, eds., Handbook of Regional and Urban Economics Volume 3 (1999), pp. 1559-1594. 
Table 1: Number of Subsidized Housing Units, By Program

\begin{tabular}{lc}
\hline \multicolumn{1}{c}{ Program } & Number of housing units \\
\hline Public & $1,326,224$ \\
Indian & 67,744 \\
Section 8 Certificates and Vouchers & $1,346,306$ \\
Section 8 Moderate Rehabilitation & 105,845 \\
Section 8 New Construction and Substantial Rehabilitation & 897,160 \\
Section 236 & 447,382 \\
Other Subsidy & 292,237 \\
Low-Income Housing Tax Credit & 332,085 \\
Total & $4,814,983$ \\
\hline
\end{tabular}

Source: A Picture of Subsidized Households, December 1996; www.huduser.org These figures are for HUD rental subsidy programs and the LIHTC only, and as such do not reflect owneroccupied units that receive subsidies through various programs. 
Table 2: Summary Statistics

\begin{tabular}{|c|c|c|c|c|}
\hline & \multicolumn{2}{|c|}{ Place Level } & \multicolumn{2}{|c|}{ MSA Level } \\
\hline Variable & Mean & $\begin{array}{c}\text { Standard } \\
\text { Deviation }\end{array}$ & Mean & $\begin{array}{c}\text { Standard } \\
\text { Deviation }\end{array}$ \\
\hline Occupied housing units per capita & 0.376 & 0.045 & 0.369 & 0.021 \\
\hline $\begin{array}{l}\text { Occupied subsidized housing units per } \\
\text { capita }\end{array}$ & 0.018 & 0.016 & 0.016 & 0.005 \\
\hline $\begin{array}{l}\text { Occupied project-based housing units } \\
\text { per capita }\end{array}$ & 0.013 & 0.013 & 0.011 & 0.005 \\
\hline $\begin{array}{l}\text { Occupied tenant-based housing units } \\
\text { per capita }\end{array}$ & 0.005 & 0.005 & 0.005 & 0.002 \\
\hline Subsidized housing "Pressure" & 0.322 & 0.270 & 0.298 & 0.104 \\
\hline Subsidized units * Pressure & 0.010 & 0.021 & 0.005 & 0.004 \\
\hline Percent $65+$ & 0.130 & 0.060 & 0.118 & 0.029 \\
\hline Percent Black & 0.140 & 0.175 & 0.129 & 0.083 \\
\hline Percent American Indian & 0.007 & 0.035 & 0.005 & 0.008 \\
\hline Percent Asian & 0.037 & 0.067 & 0.036 & 0.054 \\
\hline Percent other race & 0.049 & 0.076 & 0.049 & 0.056 \\
\hline Percent married & 0.396 & 0.078 & 0.410 & 0.028 \\
\hline $\begin{array}{l}\text { Percent who moved to the area in the } \\
\text { last five years }\end{array}$ & 0.201 & 0.102 & 0.169 & 0.059 \\
\hline Rooms per capita & 2.144 & 0.382 & 2.141 & 0.221 \\
\hline
\end{tabular}

Notes: Summary statistics are weighted by population. The number of observations underlying the place-level statistics is 22,872 , except for the rows incorporating subsidized housing "pressure," which have 22,632 observations. The MSA-level statistics have 252 observations in all cases. "Percent who moved to the area in the last five years," in the case of the place-level data, is the share of persons who lived outside the county five years ago. For the MSA-level data, it is the share of persons who lived outside the MSA five years ago. 
Table 3: Geographic Distributions

Census Designated Places

\begin{tabular}{ccccccc} 
Percent of Census & $\begin{array}{c}\text { Percent of } \\
\text { subsidized } \\
\text { housing } \\
\text { units in } \\
\text { sample }\end{array}$ & $\begin{array}{c}\text { Percent of } \\
\text { total } \\
\text { housing } \\
\text { units }\end{array}$ & $\begin{array}{c}\text { Percent of } \\
\text { population }\end{array}$ & $\begin{array}{c}\text { Number of } \\
\text { subsidized } \\
\text { housing } \\
\text { units per } \\
\text { capita }\end{array}$ & $\begin{array}{c}\text { Aumber of } \\
\text { Avensuse } \\
\text { Population }\end{array}$ & $\begin{array}{c}\text { Designated } \\
\text { Places }\end{array}$ \\
\hline Full sample & 100.0 & 100.0 & 100.0 & 0.019 & 7,817 & 22,872 \\
Top 50 percent & 98.6 & 96.4 & 96.7 & 0.019 & 15,114 & 11,434 \\
Top 25 percent & 93.4 & 88.0 & 88.5 & 0.020 & 27,661 & 5,718 \\
Top 10 percent & 81.9 & 72.7 & 73.1 & 0.021 & 57,116 & 2,287 \\
Top 5 percent & 72.2 & 60.5 & 60.5 & 0.022 & 94,640 & 1,143 \\
\hline
\end{tabular}

Metropolitan Statistical Areas

\begin{tabular}{ccccccc} 
& $\begin{array}{c}\text { Percent of } \\
\text { subsidized } \\
\text { housing } \\
\text { units in } \\
\text { sample }\end{array}$ & $\begin{array}{c}\text { Percent of } \\
\text { total } \\
\text { housing } \\
\text { units }\end{array}$ & $\begin{array}{c}\text { Percent of } \\
\text { population } \\
\text { population }\end{array}$ & $\begin{array}{c}\text { Number of } \\
\text { subsidized } \\
\text { housing } \\
\text { units per } \\
\text { capita }\end{array}$ & $\begin{array}{c}\text { Average } \\
\text { Population }\end{array}$ & $\begin{array}{c}\text { Number of } \\
\text { MSAs }\end{array}$ \\
\hline Full sample & 100.0 & 100.0 & 100.0 & 0.017 & 690,358 & 252 \\
Top 50 percent & 89.4 & 89.8 & 90.0 & 0.017 & $1,242,803$ & 126 \\
Top 25 percent & 77.1 & 77.1 & 77.4 & 0.017 & $3,010,888$ & 63 \\
Top 10 percent & 58.3 & 58.7 & 59.3 & 0.017 & $4,062,213$ & 25 \\
\hline
\end{tabular}


Table 4: Population, Subsidized and Total Housing Units, Eligibles, and Crowdedness for the Top 35 Places Ranked by Subsidized Housing

\begin{tabular}{|c|c|c|c|c|c|c|}
\hline Place & Population & $\begin{array}{c}\text { Total } \\
\text { subsidized } \\
\text { housing }\end{array}$ & $\begin{array}{c}\text { Total } \\
\text { housing } \\
\text { units }\end{array}$ & $\begin{array}{l}\text { Imputed } \\
\text { number of } \\
\text { eligibles }\end{array}$ & $\begin{array}{c}\text { Rooms per } \\
\text { capita }\end{array}$ & $\begin{array}{l}\text { Persons } \\
\text { per unit }\end{array}$ \\
\hline New York & $7,322,564$ & 249,924 & $2,992,169$ & 455,108 & 1.68 & 2.45 \\
\hline Chicago & $2,783,726$ & 83,344 & $1,133,039$ & 181,758 & 1.92 & 2.46 \\
\hline Los Angeles & $3,485,398$ & 54,272 & $1,299,963$ & 192,818 & 1.54 & 2.68 \\
\hline Baltimore & 736,014 & 38,298 & 303,706 & 44,852 & 2.21 & 2.42 \\
\hline Philadelphia & $1,585,577$ & 36,831 & 674,899 & 108,167 & 2.28 & 2.35 \\
\hline Boston & 574,283 & 30,923 & 250,863 & 29,793 & 1.94 & 2.29 \\
\hline Dallas & $1,006,831$ & 30,700 & 465,579 & 60,720 & 2.17 & 2.16 \\
\hline Atlanta & 394,017 & 25,923 & 182,754 & 29,430 & 2.27 & 2.16 \\
\hline Detroit & $1,027,974$ & 24,857 & 410,027 & 80,457 & 2.14 & 2.51 \\
\hline Houston & $1,630,672$ & 22,319 & 726,402 & 112,197 & 2.09 & 2.24 \\
\hline Newark & 275,221 & 21,906 & 102,473 & 18,926 & 1.64 & 2.69 \\
\hline Columbus & 632,958 & 21,889 & 278,102 & 34,692 & 2.29 & 2.28 \\
\hline Cleveland & 505,616 & 21,660 & 224,311 & 36,979 & 2.34 & 2.25 \\
\hline San Antonio & 935,927 & 20,363 & 365,400 & 61,220 & 1.89 & 2.56 \\
\hline Pittsburgh & 369,879 & 19,955 & 170,159 & 22,830 & 2.40 & 2.17 \\
\hline San Francisco & 723,959 & 19,749 & 328,471 & 36,163 & 1.86 & 2.20 \\
\hline New Orleans & 496,938 & 19,605 & 225,573 & 37,719 & 2.18 & 2.20 \\
\hline St. Louis & 396,685 & 18,678 & 194,919 & 23,590 & 2.27 & 2.04 \\
\hline Milwaukee & 628,088 & 18,322 & 254,204 & 39,120 & 2.00 & 2.47 \\
\hline Nashville-Davidson & 488,518 & 17,838 & 219,521 & 27,298 & 2.31 & 2.23 \\
\hline Memphis & 610,337 & 16,728 & 248,573 & 41,727 & 2.14 & 2.46 \\
\hline Seattle & 516,259 & 16,344 & 249,032 & 22,026 & 2.34 & 2.07 \\
\hline Cincinnati & 364,040 & 15,732 & 169,088 & 24,317 & 2.20 & 2.15 \\
\hline Kansas City & 435,141 & 15,332 & 201,773 & 25,480 & 2.47 & 2.16 \\
\hline Denver & 467,610 & 14,784 & 239,636 & 27,871 & 2.56 & 1.95 \\
\hline Oakland & 372,242 & 14,398 & 154,737 & 23,714 & 1.84 & 2.41 \\
\hline Louisville & 269,157 & 13,775 & 124,062 & 19,523 & 2.29 & 2.17 \\
\hline Minneapolis & 368,383 & 13,671 & 172,666 & 18,947 & 2.27 & 2.13 \\
\hline Birmingham & 265,852 & 13,254 & 117,636 & 17,501 & 2.31 & 2.26 \\
\hline San Diego & $1,110,549$ & 12,263 & 431,722 & 54,311 & 1.82 & 2.57 \\
\hline Buffalo & 328,123 & 12,125 & 151,971 & 21,446 & 2.55 & 2.16 \\
\hline St. Paul & 272,235 & 12,011 & 117,583 & 14,113 & 2.16 & 2.32 \\
\hline E1 Paso & 515,342 & 11,334 & 168,625 & 36,701 & 1.68 & 3.06 \\
\hline Portland & 437,398 & 11,331 & 198,319 & 22,575 & 2.35 & 2.21 \\
\hline Akron & 223,019 & 10,936 & 96,372 & 13,942 & 2.37 & 2.31 \\
\hline Total: & $32,556,532$ & $1,001,374$ & $13,644,329$ & $2,018,031$ & & \\
\hline
\end{tabular}

Sources: Population, total housing, subsidized housing, eligibles, and rooms per capita: 1990 Census. Subsidized housing data are derived from HUD's Picture of Subsidized Housing, 1996. 
Table 5: The Effect of Subsidized Housing on

Total Occupied Housing Units

\begin{tabular}{|c|c|c|c|c|}
\hline & (1) & (2) & (3) & (4) \\
\hline $\begin{array}{l}\text { Occupied subsidized housing } \\
\text { units per capita }\end{array}$ & $\begin{array}{c}0.276 \\
(0.012)\end{array}$ & $\begin{array}{c}0.354 \\
(0.013)\end{array}$ & $\begin{array}{c}0.173 \\
(0.135)\end{array}$ & $\begin{array}{c}0.518 \\
(0.157)\end{array}$ \\
\hline Percent Black & $\begin{array}{l}-0.028 \\
(0.001)\end{array}$ & $\begin{array}{l}-0.024 \\
(0.002)\end{array}$ & $\begin{array}{l}-0.011 \\
(0.011)\end{array}$ & $\begin{array}{c}0.028 \\
(0.016)\end{array}$ \\
\hline Percent American Indian & $\begin{array}{l}-0.030 \\
(0.004)\end{array}$ & $\begin{array}{l}-0.055 \\
(0.004)\end{array}$ & $\begin{array}{c}0.295 \\
(0.068)\end{array}$ & $\begin{array}{c}0.359 \\
(0.128)\end{array}$ \\
\hline Percent Asian & $\begin{array}{l}-0.072 \\
(0.002)\end{array}$ & $\begin{array}{l}-0.077 \\
(0.004)\end{array}$ & $\begin{array}{l}-0.072 \\
(0.011)\end{array}$ & $\begin{array}{c}-.115 \\
(0.048)\end{array}$ \\
\hline Percent other race & $\begin{array}{l}-0.114 \\
(0.003)\end{array}$ & $\begin{array}{l}-0.118 \\
(0.003)\end{array}$ & $\begin{array}{l}-0.052 \\
(0.021)\end{array}$ & $\begin{array}{l}-0.013 \\
(0.026)\end{array}$ \\
\hline Percent married & $\begin{array}{c}0.018 \\
(0.005)\end{array}$ & $\begin{array}{l}-0.030 \\
(0.006)\end{array}$ & $\begin{array}{c}0.103 \\
(0.041)\end{array}$ & $\begin{array}{c}0.055 \\
(0.055)\end{array}$ \\
\hline Constant & $\begin{array}{c}0.292 \\
(0.029)\end{array}$ & $\begin{array}{c}0.347 \\
(0.028)\end{array}$ & $\begin{array}{l}-0.503 \\
(0.798)\end{array}$ & $\begin{array}{c}0.325 \\
(0.580)\end{array}$ \\
\hline State dummies & No & Yes & No & Yes \\
\hline Other covariates & Yes & Yes & Yes & Yes \\
\hline Unit of observation & Place & Place & MSA & MSA \\
\hline Number of observations & 22,872 & 22,872 & 252 & 252 \\
\hline Adjusted $R^{2}$ & 0.76 & 0.79 & 0.89 & 0.94 \\
\hline
\end{tabular}

Notes: Left-hand-side variable is occupied housing units per capita. Standard errors are in parentheses. Regressions are OLS, weighted by population. In columns (1) and (2) the observations consist of Census-designated places. In column (3), the observations are on metropolitan statistical areas. The omitted race category is "white." The "other" covariates that are included but not reported are: the income distribution across 25 categories and the age distribution across 12 categories. Specifications (2) and (4) add state dummies. 
Table 6: The Effect of Subsidized Housing on Occupied Housing Units, by population of the Census-designated place

\begin{tabular}{lccc}
\hline $\begin{array}{l}\text { Percent of Census Places, } \\
\text { ranked by population }\end{array}$ & $(1)$ & $(2)$ & $(3)$ \\
\cline { 2 - 4 } Bottom quartile & 0.060 & 0.058 & 0.051 \\
& $(0.021)$ & $(0.020)$ & $(0.025)$ \\
Second quartile & 0.166 & 0.163 & 0.153 \\
& $(0.022)$ & $(0.021)$ & $(0.021)$ \\
Third quartile & 0.248 & 0.231 & 0.209 \\
& $(0.024)$ & $(0.024)$ & $(0.023)$ \\
Top quartile & 0.225 & 0.377 & 0.346 \\
& $(0.025)$ & $(0.026)$ & $(0.027)$ \\
State dummies & No & Yes & Yes \\
\hline
\end{tabular}

Notes: Left-hand-side variable is occupied housing units per capita. The reported coefficients are the estimates for "occupied subsidized housing units per capita." Standard errors are in parentheses. Each observation is a Census-designated place. Specifications (1) and (2) are weighted by population, specification (3) is not. All regressions include controls for the age, race, and income distributions, and the percent married. Specifications (2) and (3) add state dummies. 
Table 7: Crowd-Out is Lower in Places Where There is Less Subsidized Housing Relative to the Needy Population

\begin{tabular}{|c|c|c|}
\hline & (1) & (2) \\
\hline $\begin{array}{l}\text { Occupied subsidized housing units } \\
\text { per capita }\end{array}$ & $\begin{array}{c}0.375 \\
(0.041)\end{array}$ & $\begin{array}{c}0.506 \\
(0.040)\end{array}$ \\
\hline Subsidized housing "Pressure" & $\begin{array}{c}0.004 \\
(0.002)\end{array}$ & $\begin{array}{c}0.001 \\
(0.002)\end{array}$ \\
\hline Subsidized units * Pressure & $\begin{array}{l}-0.150 \\
(0.011)\end{array}$ & $\begin{array}{l}-0.133 \\
(0.010)\end{array}$ \\
\hline \multicolumn{3}{|l|}{$\begin{array}{l}\partial(\text { occupied housing }) / \partial(\text { subsidized } \\
\text { housing) evaluated at: }\end{array}$} \\
\hline $\begin{array}{l}\text { Low pressure: } \\
25^{\text {th }} \text { percentile }(0.511)\end{array}$ & $\begin{array}{c}0.298 \\
(0.041)\end{array}$ & $\begin{array}{c}0.438 \\
(0.039)\end{array}$ \\
\hline $\begin{array}{l}\text { Medium pressure: } \\
50^{\text {th }} \text { percentile }(0.282)\end{array}$ & $\begin{array}{c}0.332 \\
(0.041)\end{array}$ & $\begin{array}{c}0.468 \\
(0.039)\end{array}$ \\
\hline $\begin{array}{l}\text { High pressure: } \\
75^{\mathrm{th}} \text { percentile }(0.093)\end{array}$ & $\begin{array}{c}0.361 \\
(0.041)\end{array}$ & $\begin{array}{c}0.493 \\
(0.040)\end{array}$ \\
\hline State dummies & No & Yes \\
\hline Unit of observation & Place & Place \\
\hline Number of observations & 22,632 & 22,632 \\
\hline Adjusted $\mathrm{R}^{2}$ & 0.77 & 0.80 \\
\hline
\end{tabular}

Notes: Left-hand-side variable is occupied housing units per capita. Standard errors are in parentheses. Regressions are OLS, weighted by population. The observations consist of 22,632 Census-designated places. Subsidized housing "Pressure" is the number of subsidized housing units divided by the number of people that have less than 50 percent of the median family income. All regressions also include controls for the age, race, and income distributions, and the percent married. Specification (2) adds state dummies. 
Table 8: Do Project-based and Tenant-based Assistance Have Different Rates of Crowd-Out?

\begin{tabular}{|c|c|c|c|c|c|c|c|c|}
\hline & \multicolumn{2}{|c|}{ Project-based assistance } & \multicolumn{2}{|c|}{ Tenant-based assistance } & \multicolumn{4}{|c|}{ Project and Tenant-based Assistance } \\
\hline & $(1)$ & $(2)$ & (3) & (4) & $(5)$ & $(6)$ & $(7)$ & $(8)$ \\
\hline $\begin{array}{l}\text { Occupied project- } \\
\text { based housing } \\
\text { per capita }\end{array}$ & $\begin{array}{c}0.209 \\
(0.015)\end{array}$ & $\begin{array}{c}0.313 \\
(0.015)\end{array}$ & & & $\begin{array}{c}0.167 \\
(0.014)\end{array}$ & $\begin{array}{c}0.278 \\
(0.015)\end{array}$ & $\begin{array}{c}0.049 \\
(0.173)\end{array}$ & $\begin{array}{c}0.696 \\
(0.213)\end{array}$ \\
\hline $\begin{array}{l}\text { Occupied tenant- } \\
\text { based housing } \\
\text { per capita }\end{array}$ & & & $\begin{array}{c}0.720 \\
(0.030)\end{array}$ & $\begin{array}{c}0.681 \\
(0.030)\end{array}$ & $\begin{array}{c}0.673 \\
(0.030)\end{array}$ & $\begin{array}{c}0.617 \\
(0.030)\end{array}$ & $\begin{array}{c}0.429 \\
(0.289)\end{array}$ & $\begin{array}{c}0.238 \\
(0.276)\end{array}$ \\
\hline State dummies & No & Yes & No & Yes & No & Yes & No & Yes \\
\hline $\begin{array}{l}\text { Unit of } \\
\text { observation }\end{array}$ & Place & Place & Place & Place & Place & Place & MSA & MSA \\
\hline $\begin{array}{l}\text { Number of } \\
\text { observations }\end{array}$ & 22,872 & 22,872 & 22,872 & 22,872 & 22,872 & 22,872 & 252 & 252 \\
\hline $\begin{array}{l}\text { Adjusted R- } \\
\text { squared }\end{array}$ & 0.76 & 0.79 & 0.77 & 0.79 & 0.77 & 0.80 & 0.89 & 0.94 \\
\hline
\end{tabular}

Notes: Left-hand-side variable is occupied housing units per capita. Standard errors are in parentheses. Regressions are OLS, weighted by population. In columns (1) through (6) the observations consist of Census-designated places. In columns (7) and (8), the observations are on metropolitan statistical areas. Regressions are weighted by population. All regressions also include controls for the age, race, and income distributions, and the percent married. 
Table 9: The Effect of Subsidized Housing on Total Occupied Housing Units, Instrumental Variables Estimates

\begin{tabular}{|c|c|c|c|c|c|c|}
\hline \multirow[b]{2}{*}{$\begin{array}{l}\text { Occupied subsidized housing } \\
\text { units per capita (1996) }\end{array}$} & \multicolumn{2}{|c|}{$\begin{array}{l}\text { Instruments: Occupied public } \\
\text { housing units per capita ( } 1980 \text { ) } \\
\text { and Number of housing units } \\
\text { per capita built before } 1940\end{array}$} & \multicolumn{2}{|c|}{$\begin{array}{l}\text { Instrument: Occupied public } \\
\text { housing units per capita (1980) }\end{array}$} & \multicolumn{2}{|c|}{$\begin{array}{c}\text { Instrument: Number of housing } \\
\text { units per capita built before } \\
1940\end{array}$} \\
\hline & $\begin{array}{c}0.057 \\
(0.028)\end{array}$ & $\begin{array}{c}0.395 \\
(0.031)\end{array}$ & $\begin{array}{c}0.026 \\
(0.030)\end{array}$ & $\begin{array}{c}0.183 \\
(0.032)\end{array}$ & $\begin{array}{c}0.157 \\
(0.051)\end{array}$ & $\begin{array}{c}1.970 \\
(0.093)\end{array}$ \\
\hline State dummies & No & Yes & No & Yes & No & Yes \\
\hline Adjusted $\mathrm{R}^{2}$ & 0.76 & 0.79 & 0.76 & 0.79 & 0.76 & 0.65 \\
\hline
\end{tabular}

Notes: Left-hand-side variable is occupied housing units per capita. Standard errors are in parentheses. There are 21,237 observations in columns (1), (2), (5) and (6), and 22,872 in colums (3) and (4). Each is a Census-designated place. Regressions are weighted by population. All regressions also include controls for the age, race, and income distributions, and the percent married. Occupied subsidized housing units per capita is an endogenous variable in these regressions and the variables at the top of the columns are added to the instrument set. 
Table 10: Subsidized housing and immigration

\begin{tabular}{|c|c|c|c|c|c|c|c|c|c|}
\hline & \multicolumn{9}{|c|}{ Left-hand-side variable } \\
\hline & \multicolumn{3}{|c|}{ Immigration per capita } & \multicolumn{6}{|c|}{ Occupied housing units per capita } \\
\hline & $(1)$ & $(2)$ & (3) & (4) & $(5)$ & $(6)$ & (7) & $(8)$ & (9) \\
\hline $\begin{array}{l}\text { Occupied subsidized } \\
\text { housing units per capita }\end{array}$ & $\begin{array}{l}-0.146 \\
(0.039)\end{array}$ & $\begin{array}{c}0.213 \\
(0.037)\end{array}$ & $\begin{array}{l}-0.940 \\
(0.554)\end{array}$ & $\begin{array}{c}0.281 \\
(0.012)\end{array}$ & $\begin{array}{c}0.356 \\
(0.013)\end{array}$ & $\begin{array}{c}0.392 \\
(0.042)\end{array}$ & $\begin{array}{c}0.512 \\
(0.040)\end{array}$ & $\begin{array}{c}0.223 \\
(0.133)\end{array}$ & $\begin{array}{c}0.520 \\
(0.157)\end{array}$ \\
\hline Immigration per capita & & & & $\begin{array}{c}0.014 \\
(0.002)\end{array}$ & $\begin{array}{c}0.007 \\
(0.002)\end{array}$ & $\begin{array}{c}0.017 \\
(0.002)\end{array}$ & $\begin{array}{c}0.008 \\
(0.002)\end{array}$ & $\begin{array}{c}0.053 \\
(0.016)\end{array}$ & $\begin{array}{l}-0.012 \\
(0.022)\end{array}$ \\
\hline $\begin{array}{l}\text { Subsidized housing } \\
\text { "Pressure" }\end{array}$ & & & & & & $\begin{array}{c}0.007 \\
(0.002)\end{array}$ & $\begin{array}{c}0.002 \\
(0.002)\end{array}$ & & \\
\hline $\begin{array}{l}\text { Subsidized units * } \\
\text { Pressure }\end{array}$ & & & & & & $\begin{array}{l}-0.152 \\
(0.011)\end{array}$ & $\begin{array}{l}-0.133 \\
(0.010)\end{array}$ & & \\
\hline Immigration * Pressure & & & & & & $\begin{array}{l}-0.049 \\
(0.007)\end{array}$ & $\begin{array}{l}-0.025 \\
(0.007)\end{array}$ & & \\
\hline State dummies & No & Yes & No & No & Yes & No & Yes & No & Yes \\
\hline Unit of observation & Place & Place & MSA & Place & Place & Place & Place & MSA & MSA \\
\hline $\begin{array}{l}\text { Number of } \\
\text { observations: }\end{array}$ & 22,872 & 22,872 & 252 & 22,872 & 22,872 & 22,632 & 22,632 & 252 & 252 \\
\hline Adjusted $\mathrm{R}^{2}$ & 0.55 & 0.66 & 0.78 & 0.76 & 0.79 & 0.77 & 0.80 & 0.90 & 0.94 \\
\hline
\end{tabular}

Notes: Standard errors are in parentheses. Regressions are OLS, weighted by population. In columns (1), (2), and (4)-(7) the observations consist of Census-designated places. In columns (3), (8), and (9) the observations are on metropolitan statistical areas. Subsidized housing "Pressure" is the number of subsidized housing units divided by the number of people that have less than 50 percent of the median family income. All regressions include controls for the age, racial, and income distributions, and the percent married. Columns (2), (5), (7), and (9) include state dummies. 
Table 11: Does subsidized housing affect the num ber of rooms?

\begin{tabular}{|c|c|c|c|c|c|c|c|c|}
\hline \multirow[t]{2}{*}{ Left-hand-side variable: } & \multicolumn{4}{|c|}{ Rooms per capita } & \multicolumn{4}{|c|}{ Rooms per unit } \\
\hline & (1) & (2) & (3) & (4) & $(5)$ & (6) & (7) & (8) \\
\hline $\begin{array}{l}\text { Occupied subsidized } \\
\text { housing units per capita }\end{array}$ & $\begin{array}{c}0.989 \\
(0.119)\end{array}$ & $\begin{array}{c}0.569 \\
(0.117)\end{array}$ & $\begin{array}{c}2.917 \\
(1.412)\end{array}$ & $\begin{array}{c}4.589 \\
(1.801)\end{array}$ & $\begin{array}{c}0.892 \\
(0.181)\end{array}$ & $\begin{array}{l}-1.786 \\
(0.165)\end{array}$ & $\begin{array}{l}5.795 \\
(2.696)\end{array}$ & $\begin{array}{c}3.661 \\
(2.496)\end{array}$ \\
\hline State dummies & No & Yes & No & Yes & No & Yes & No & Yes \\
\hline Adjusted $\mathrm{R}^{2}$ & 0.68 & 0.73 & 0.89 & 0.92 & 0.77 & 0.84 & 0.84 & 0.94 \\
\hline Unit of observation & Place & Place & MSA & MSA & Place & Place & MSA & MSA \\
\hline \multirow[t]{2}{*}{ Left-hand-side variable: } & \multicolumn{4}{|c|}{ Rooms per capita } & \multicolumn{4}{|c|}{ Occupied housing units per capita } \\
\hline & (9) & $(10)$ & $(11)$ & (12) & (13) & (14) & (15) & (16) \\
\hline $\begin{array}{l}\text { Occupied subsidized } \\
\text { housing units per capita }\end{array}$ & $\begin{array}{c}0.757 \\
(0.109)\end{array}$ & $\begin{array}{c}0.982 \\
(0.111)\end{array}$ & $\begin{array}{c}1.432 \\
(1.248)\end{array}$ & $\begin{array}{c}3.359 \\
(1.597)\end{array}$ & $\begin{array}{c}0.282 \\
(0.012)\end{array}$ & $\begin{array}{c}0.308 \\
(0.012)\end{array}$ & $\begin{array}{c}0.253 \\
(0.130)\end{array}$ & $\begin{array}{c}0.498 \\
(0.157)\end{array}$ \\
\hline Rooms per unit & $\begin{array}{c}0.261 \\
(0.004)\end{array}$ & $\begin{array}{c}0.231 \\
(0.004)\end{array}$ & $\begin{array}{c}0.256 \\
(0.032)\end{array}$ & $\begin{array}{c}0.336 \\
(0.049)\end{array}$ & $\begin{array}{l}-0.0143 \\
(0.0004)\end{array}$ & $\begin{array}{l}-0.0202 \\
(0.0005)\end{array}$ & $\begin{array}{l}-0.015 \\
(0.003)\end{array}$ & $\begin{array}{c}0.006 \\
(0.005)\end{array}$ \\
\hline State dummies & No & Yes & No & Yes & No & Yes & No & Yes \\
\hline Adjusted $\mathrm{R}^{2}$ & 0.73 & 0.76 & 0.92 & 0.94 & 0.78 & 0.81 & 0.90 & 0.94 \\
\hline Unit of observation & Place & Place & MSA & MSA & Place & Place & MSA & MSA \\
\hline
\end{tabular}

Notes: Standard errors are in parentheses. Regressions are OLS, weighted by population. Specifications using census-designated places have 22,872 observations and the columns with metropolitan statistical areas have 252 observations. All regressions include controls for the age, racial, and income distributions, and the percent married. Even numbered columns include state dummies. 
Appendix Table A: First-Stage Regressions

The Relationship Between Preexisting Public Housing or

Old Rental Stock and Current Subsidized Housing

\begin{tabular}{|c|c|c|c|c|}
\hline \multirow[b]{2}{*}{$\begin{array}{l}\text { Occupied public units in } \\
1977 \text { per } 1990 \text { capita }\end{array}$} & \multicolumn{2}{|c|}{$\begin{array}{c}\text { Instrument: Occupied public } \\
\text { housing units per capita (1980) }\end{array}$} & \multicolumn{2}{|c|}{$\begin{array}{l}\text { Instrument: Number of } \\
\text { Housing units per capita } \\
\text { built before } 1940\end{array}$} \\
\hline & $\begin{array}{c}0.670 \\
(0.010)\end{array}$ & $\begin{array}{c}0.604 \\
(0.009)\end{array}$ & & \\
\hline $\begin{array}{l}\text { \# of rental units per capita } \\
\text { built pre- } 1940\end{array}$ & & & $\begin{array}{c}0.111 \\
(0.003)\end{array}$ & $\begin{array}{c}0.103 \\
(0.004)\end{array}$ \\
\hline State dummies & No & Yes & No & Yes \\
\hline Adjusted $\mathrm{R}^{2}$ & 0.56 & 0.61 & 0.48 & 0.55 \\
\hline
\end{tabular}

Notes: Left-hand-side variable is occupied subsidized housing units per capita in 1990. Standard errors are in parentheses. There are 21,237 observations in columns (1) and (2) and 22,872 in colums (3) and (4), each is a Census-designated place. Regressions are weighted by population. All regressions also include controls for the age, race, and income distributions, and the percent married. 